\title{
PENGARUH JENIS KOTORAN TERNAK SEBAGAI SUBSTRAT DENGAN PENAMBAHAN SERASAH DAUN JATI (Tectona grandis) TERHADAP KARAKTERISTIK BIOGAS PADA PROSES FERMENTASI
}

\section{EFFECT VARIOUS TYPES OF MANURE AS A SUBSTRATE ON THE CHARACTERISTIC OF FERMENTATION WITH ADDITION LEAF TEAK (Tectona grandis)}

\author{
Ludfia Windyasmara*, Ambar Pertiwiningrum, dan Lies Mira Yusiati \\ Fakultas Peternakan, Universitas Gadjah Mada, Jl. Fauna No. 3, Bulaksumur, Yogyakarta, 55281
}

\section{INTISARI}

\begin{abstract}
Biogas adalah gas yang dihasilkan dari aktivitas biologi dalam proses fermentasi anaerob dan sebagai energi terbarukan. Penelitian bertujuan untuk mengetahui pengaruh penggunaan kotoran sapi dan kuda sebagai substrat dalam pembentukan gas metan pada proses fermentasi. Percobaan dilakukan dengan 2 perlakuan, yaitu P1 untuk perlakuan biogas dengan kotoran sapi dan P2 untuk perlakuan dengan menggunakan kotoran kuda. Pada setiap perlakuan terdiri atas 3 level, yaitu dengan penambahan serasah daun jati sebanyak 0, 5, dan 10\%. Penelitian dilakukan sebanyak 3 kali ulangan dengan pengambilan sampel sebanyak 4 kali pada hari ke-10, 20, 30, dan 40. Variabel yang diukur adalah volume biogas, kadar gas metan, dan produksi gas metan. Pengolahan data penelitian menggunakan perhitungan analisis split-plot. Hasil penelitian menunjukkan bahwa terjadi perbedaan yang signifikan terhadap biogas dengan substrat kotoran sapi dan kotoran kuda yang disebabkan oleh perbedaan sistem pencernaan antara sapi dan kuda sehingga mengakibatkan kandungan bahan organik dalam feses kuda lebih tinggi daripada bahan organik dalam feses sapi. Selain itu interaksi waktu juga mempengaruhi produksi biogas sebagai hasil akhirnya. Namun demikian, penambahan serasah daun jati tidak memiliki interaksi positif terhadap peningkatan produksi biogas, hal ini disebabkan karena terdapatnya kandungan tanin dalam daun jati.
\end{abstract}

(Kata kunci: Kotoran sapi, Kotoran kuda, Serasah daun jati, Biogas)

\section{ABSTRACT}

Biogas was produced from biological activities in anaerobic fermentation and as a renewable energy. This experiment was carried out to find out the effect of the use of cow and horse manures as a substrate in the formation of methane in the fermentation process. This experiment was conducted was two treatments, ie. P1 for biogas treatment with cow manure and $P 2$ for the treatment using horse manure. Each treatment consisted of three levels, ie. the addition of teak leaf litter at 0, 5, and 10\%. This experiment was done 3 times by repeated sampling as much as 4 times on day $10^{\text {th }}, 20^{\text {th }}, 30^{\text {th }}$ and the $40^{\text {th }}$. The variables measured were the volume of biogas, the levels of metan gas and methane gas production. This experiment use data processing calculations of split-plot analysis. The results showed that there was a significant difference to the cow manure and horse manure as a biogas substrate caused by the differences in the digestive system of cows and the horses, resulting in organic matter in horses manure is higher that the organic matter in the cows manure. Besides the interaction of time also affects the production of biogas as an end result. The addition of teak leaf litter had no positive interaction on the production of biogas, this is possible because the presence of tanin content in leaves of teak.

(Keyword: Cow manure, Horse manure, Leaf litter teak, Biogas)

\section{Pendahuluan}

Indonesia mempunyai potensi yang baik di bidang peternakan, namun selama ini belum dikembangkan sepenuhnya. Hal ini disebabkan sebagian besar peternakan di Indonesia adalah peternakan yang bersifat tradisonal, termasuk dalam pengolahan hasil dan limbahnya belum tersentuh

\footnotetext{
* Korespondensi (corresponding author):

Telp. +6285643450266

E-mail: windyasmaraludfia@yahoo.co.id
}

teknologi. Peternak biasanya menumpuk feses sebelum membuang atau membawanya ke sawah. Perlunya pengolahan limbah yang tepat akan dapat mengurangi dampak pencemaran terhadap lingkungan. Berdasarkan kondisi tersebut, maka perlu adanya teknologi tepat guna yang dapat memanfaatkan limbah sehingga dapat mengurangi pencemaran terhadap lingkungan sekaligus menjadi sumber energi terbarukan yang dapat mengatasi permasalahan energi.

Menurut Widodo (2006), kandungan nutrien utama untuk bahan pengisi biogas adalah nitrogen, 
fosfor dan kalium. Kandungan nitrogen dalam bahan sebaiknya sebesar $1,45 \%$, sedangkan fosfor dan kalium masing-masing sebesar $1,10 \%$. Nutrien utama tersebut dapat diperoleh dari substrat kotoran ternak dan sampah daun yang dapat meningkatkan ratio $\mathrm{C} / \mathrm{N}$ dalam biogas.

Feses sapi mengandung hemisellulosa sebesar $18,6 \%$, sellulosa $25,2 \%$, lignin $20,2 \%$, nitrogen $1,67 \%$, fosfat $1,11 \%$ dan kalium sebesar $0,56 \%$, sedangkan feses kuda mengandung hemisellulosa sebesar $23,5 \%$, sellulosa $27,5 \%$, lignin $14,2 \%$, nitrogen $2,29 \%$, fosfat $1,25 \%$ dan kalium sebesar 1,38\% (Sihotang, 2010). Feses sapi mempunyai $\mathrm{C} / \mathrm{N}$ ratio sebesar $16,6-25 \%$, sedangkan feses kuda mempunyai $\mathrm{C} / \mathrm{N}$ ratio sebesar 25\% (Siallagan, 2010). Produksi gas metan sangat tergantung oleh rasio $\mathrm{C} / \mathrm{N}$ dari substrat. Menurut Hartono (2009) rentang rasio $\mathrm{C} / \mathrm{N}$ antara 25-30 merupakan rentang optimum untuk proses penguraian anaerob. Jika rasio $\mathrm{C} / \mathrm{N}$ terlalu tinggi, maka nitrogen akan terkonsumsi sangat cepat oleh bakteri-bakteri metanogen untuk memenuhi kebutuhan protein dan tidak akan lagi bereaksi dengan sisa karbonnya. Sebagai hasilnya produksi gas akan rendah. Di lain pihak, jika rasio $\mathrm{C} / \mathrm{N}$ sangat rendah, nitrogen akan dibebaskan dan terkumpul dalam bentuk $\mathrm{NH}_{4} \mathrm{OH}$.

Menurut Mustafa (2004), daun kering yang termasuk sampah coklat kaya akan karbon (C) yang menjadi sumber energi atau makanan untuk mikrobia. Tanda sampah daun biasanya kering, kasar, berserat dan berwarna coklat (sampah coklat). Guguran atau serasah daun jati (Tectona grandis) yang lebar menutupi tanah melapuk secara lambat, sehingga menyulitkan tumbuhan lain berkembang. Serasah daun jati dapat memicu kebakaran hutan kecil yang justru mengakibatkan proses pemurnian tegakan jati terdorong untuk berkecambah, pada saat jenis-jenis pohon lain mati. Namun demikian, tumpukan serasah dalam jumlah besar dapat mengakibatkan kebakaran hutan yang besar dan mematikan vegetasi dalam hutan (Perum Perhutani, 2000).

Berdasarkan tinjauan di atas, kotoran sapi dan kuda menjadi suatu masalah dalam pencemaran lingkungan di peternakan, sedangkan serasah daun jati lama-kelamaan dapat menimbulkan kebakaran hutan, dibutuhkan pengolahan secara biologis. Dengan demikian, potensi kandungan bahan organik dalam kotoran ternak dan serasah daun jati dapat dimanfaatkan dalam pembuatan biogas. Penelitian mengenai optimasi dan efisiensi penggunaan kotoran sapi dan kuda dengan penambahan daun jati (Tectona grandis) sebagai substrat dalam pembuatan biogas diperlukan, sehingga akan diketahui proses fermentasi metanogenik dan produksi gas.
Penelitian bertujuan untuk mengetahui pengaruh penggunaan kotoran sapi dan kuda sebagai substrat dengan penambahan serasah daun jati (Tectona grandis) terhadap proses fermentasi volume biogas, kadar gas dan produksi gas metan.

\section{Materi dan Metode}

\section{Lokasi dan waktu penelitian}

Penelitian dilaksanakan pada tanggal $10 \mathrm{Juli}$ sampai 27 November 2010 di Laboratorium Ternak Potong dan Hewan Kesayangan, Fakultas Peternakan, Universitas Gadjah Mada. Analisis kadar metan dilaksanakan di Laboratorium Analisis dan Instrumen, Jurusan Teknik Kimia, Fakultas Teknik Universitas Gadjah Mada.

\section{Materi}

Materi penelitian yang digunakan adalah feses segar sapi Peranakan Ongole (PO), Simental Peranakan Ongole (SimPO) dan feses kuda Sanddle yang diperoleh dari Laboratorium Ternak Potong Fakultas Peternakan Universitas Gadjah Mada. Manajemen pakan yang diberikan adalah rumput gajah dan konsentrat dengan perbandingan 70:30. Serasah daun jati yang digunakan adalah guguran daun jati yang diperoleh dari Banyakan, Sitimulyo, Piyungan, Bantul.

Alat yang digunakan dalam penelitian adalah 15 unit biodigester, termometer, higrometer, kertas indikator universal $\mathrm{pH}$ 0-14 Merck untuk mengukur pH substrat, alat pengukur volume biogas. Rangkaian alat yang digunakan dalam penelitian tersaji pada Gambar reaktor anaerobik Batch I.

Rangkaian reaktor anaerobik Batch I dirancang untuk mendapatkan data-data volume gas, temperatur, dan $\mathrm{pH}$. Volume gas diukur dengan mengamati perubahan volume air pada selang, dan pengambilan sampel setiap 10 hari sekali digunakan untuk mengukur konsentrasi gas metan.

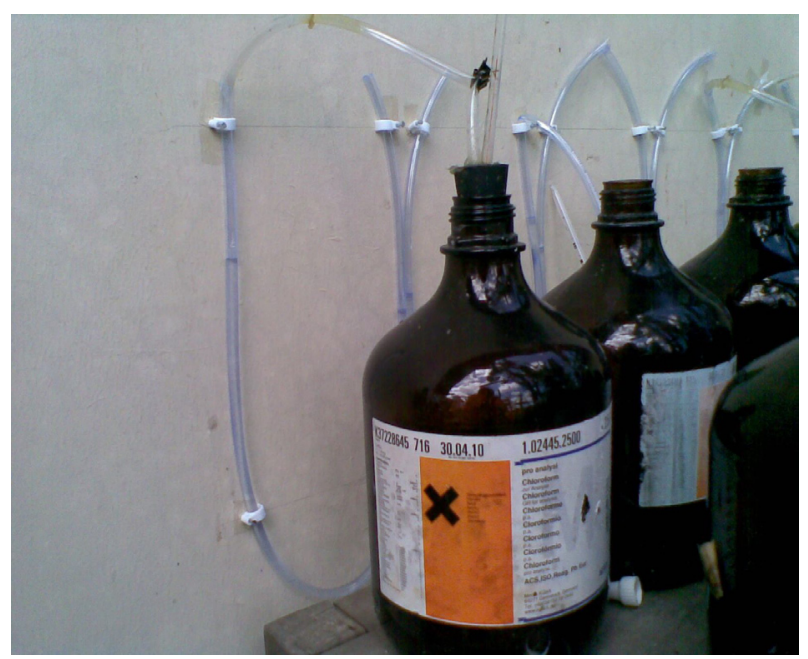

Gambar 1. Reaktor anaerobik Batch I (Batch I of anaerobic reactor) 


\section{Metode}

Penelitian berlangsung 3 tahap, tahap pertama preparasi substrat untuk pembuatan biogas, tahap kedua pembuatan biogas dan tahap ketiga analisis sampel.

Preparasi substrat. Pada penelitian ini, bahan isian diisikan ke dalam fermentor sebanyak $80 \%$ dari volume fermentor yaitu sebanyak 2 liter. Jumlah isian bahan pengisi fermentor pada proses fermentasi metanogenik tersaji pada Tabel 1.

Pembuatan biogas. Substrat yang berupa campuran kotoran ternak, guguran daun jati yang telah dihancurkan dicampur dengan air dengan perbandingan 1:2. Pengisian substrat ke dalam digester dilakukan satu kali tidak dilakukan secara continue. Substrat dasar dihancurkan terlebih dahulu dengan diremas-remas dengan dicampur dengan air agar lebih mudah hancur sehingga substrat dalam digester akan homogen. Digester diletakkan pada suhu lingkungan selama 10 sampai 40 hari. Selama pembuatan biogas, dilakukan pengamatan volume gas yang terbentuk setiap pukul 10.00 WIB, selain volume dilakukan pula pengukuran sampel gas untuk analisis kadar metan. Pengambilan sampel diulang pada pada hari ke-20, 30, dan 40.

Analisis sampel. Sampel yang dianalisis yaitu volume biogas, kadar gas metan, dan produksi metan. Volume biogas yang terbentuk diukur dengan mengamati perubahan volume air pada buret (asumsi: biogas yang dihasilkan sama dengan perubahan air yang didorong gas dalam selang). Volume gas dihitung dengan menggunakan rumus:

$$
\mathrm{V}=\pi \times \mathrm{r}^{2} \times \mathrm{t}
$$

Keterangan:

$\mathrm{V}=$ volume gas berbentuk silinder

$\pi=3,14$

$\mathrm{r}^{2}=$ jari-jari lingkaran

$\mathrm{t}=$ tinggi silinder

Kadar gas metan dianalisis dengan menggunakan metode Gas Chromatography (Asro, 2008). Preparasi sampel dilakukan dengan meng- gunakan syringe $10 \mathrm{ml}$ yang disuntikkan ke dalam selang keluar gas dan kemudian segera dimasukkan ke dalam vacutainer $10 \mathrm{ml}$ yang sudah dalam keadaan vacuum.

Produksi metan diperoleh dengan cara menghitung jumlah produksi gas yang dihasilkan dengan hasil kadar metan berdasarkan jumlah produksi gas (z) dan kadar metan (y), sehingga diperoleh perhitungan dengan rumus:

Produksi metan $=\frac{\mathrm{y}}{100} \times \mathrm{z}$

Keterangan:

y: nilai kadar metan

z: jumlah vol gas yang dihasilkan

\section{Analisis data}

Pengolahan data penelitian menggunakan perhitungan analisis split plot (SAS Institute, 1988) dengan mean-plot adalah jenis feses dan konsentrasi daun jati dan untuk sub-plotnya adalah lama inkubasi, yang digunakan untuk pengamatan pengukuran aktivitas enzim CMC-ase, kadar asam lemak volatile (VFA), volume biogas, konsentrasi gas metan, produksi metan, pengamatan temperatur sludge digester dan derajat keasaman $(\mathrm{pH})$. Hasil analisis apabila signifikan akan dilanjutkan uji analisis variansi pola searah (One-way) Anova kemudian dilanjutkan dengan Duncan's New Multiple Range Test (DMRT) (Astuti, 1981).

\section{Hasil dan Pembahasan}

\section{Volume biogas}

Rata-rata volume biogas pada tiap biogas pada berbagai perlakuan dengan beberapa level pada pengamatan setiap 10 hari sekali, tersaji pada Tabel 2.

Hasil penelitian menunjukkan bahwa volume biogas dengan substrat feses kuda menghasilkan volume biogas yang lebih tinggi dengan rerata sebesar $121,87 \mathrm{ml}$ dibandingkan volume biogas dengan biogas menggunakan substrat feses sapi

Tabel 1. Jumlah isian bahan pengisi fermentor pada proses fermentasi metanogenik (the amount of fermentor filling material in the methanogenic fermentation process)

\begin{tabular}{|c|c|c|c|c|}
\hline \multirow{2}{*}{ Perlakuan (treatment) } & \multicolumn{3}{|c|}{$\begin{array}{c}\text { Bahan isian fermentor (fermentor filling } \\
\text { materials) }\end{array}$} & \multirow{2}{*}{$\begin{array}{l}\text { Volume isian fermentor }(\mathrm{ml}) \\
\text { (fields fermentor volume }(\mathrm{ml})\end{array}$} \\
\hline & $\begin{array}{l}\text { Feses }(\mathrm{g}) \\
\text { (manure }(g))\end{array}$ & $\begin{array}{c}\text { Daun jati }(\mathrm{g}) \\
\text { (teak leaves }(\mathrm{g}) \text { ) }\end{array}$ & $\begin{array}{c}\text { Air }(\mathrm{ml}) \\
(\text { water }(\mathrm{ml}))\end{array}$ & \\
\hline \multicolumn{5}{|c|}{ Feses sapi (\%) (cow manure (\%)) } \\
\hline 0 & 670,00 & 0,00 & 1.330 & 2.000 \\
\hline 5 & 636,50 & 33,50 & 1.330 & 2.000 \\
\hline 10 & 603,00 & 67,00 & 1.330 & 2.000 \\
\hline \multicolumn{5}{|c|}{ Feses kuda (\%) (horse manure (\%)) } \\
\hline 0 & 670,00 & 0,00 & 1.330 & 2.000 \\
\hline 5 & 636,50 & 33,50 & 1.330 & 2.000 \\
\hline 10 & 603,00 & 67,00 & 1.330 & 2.000 \\
\hline
\end{tabular}


Tabel 2. Volume gas hasil fermentasi metanogenik yang menggunakan jenis kotoran ternak, konsentrasi dan waktu inkubasi yang berbeda ( $\mathrm{ml} /$ fermentor) (volume of fermentation gas methanogenic using manure types, concentrations and different incubation times (ml/ferment))

\begin{tabular}{|c|c|c|c|c|c|c|}
\hline \multirow[b]{2}{*}{ Substrat (substrate) } & \multirow{2}{*}{$\begin{array}{l}\text { Kons. daun jati }(\%)(\text { teak } \\
\text { leaves concentration }(\%))\end{array}$} & \multicolumn{5}{|c|}{ Hari ke (days) } \\
\hline & & $10\left(10^{\text {th }}\right)$ & $20\left(20^{\text {th }}\right)$ & $30\left(30^{\text {th }}\right)$ & $40\left(40^{\text {th }}\right)$ & $\begin{array}{c}\text { Rerata } \\
\text { (average) }\end{array}$ \\
\hline \multirow[t]{3}{*}{ Feses sapi (cow manure) } & 0 & 40,27 & 61,23 & 80,47 & 154,07 & $84,01^{\mathrm{c}}$ \\
\hline & 5 & 24,60 & 50,23 & 89,07 & 140,90 & $76,20^{\mathrm{c}}$ \\
\hline & 10 & 18,57 & 30,53 & 70,53 & 129,37 & $62,25^{\mathrm{d}}$ \\
\hline Rerata (average) & & 27,82 & 47,33 & 80,03 & 141,47 & 74,24 \\
\hline \multirow[t]{3}{*}{ Feses kuda (horse manure) } & 0 & 69,47 & 87,70 & 145,37 & 242,37 & $136,23^{\mathrm{a}}$ \\
\hline & 5 & 83,37 & 100,73 & 135,07 & 185,83 & $126,25^{\mathrm{a}}$ \\
\hline & 10 & 60,26 & 90,70 & 114,37 & 147,00 & $103,09^{\mathrm{b}}$ \\
\hline Rerata (average) & & 71,03 & 93,03 & 131,61 & 191,73 & 121,87 \\
\hline $\begin{array}{l}\text { *Rerata feses sapi dan kuda } \\
\text { (average of cow manure and } \\
\text { horse manure) }\end{array}$ & & $49,39^{a}$ & $70,18^{b}$ & $105,81^{\mathrm{c}}$ & $166,58^{\mathrm{d}}$ & 97,99 \\
\hline
\end{tabular}

${ }^{a, b, c, d}$ Superskrip yang berbeda pada baris/kolom yang sama menunjukkan perbedaan $(\mathrm{P}<0,05)($ different superscripts at the same row/column indicate significant differences $(P<0.05))$.

dengan rerata 74,24 $\mathrm{ml}$. Volume biogas tertinggi dihasilkan oleh biogas dengan menggunakan substrat kotoran kuda dengan penambahan serasah daun jati sebanyak $0 \%$ (tanpa penambahan) yaitu sebesar $136,23 \mathrm{ml}$, sedangkan volume biogas terendah dihasilkan oleh biogas yang menggunakan substrat kotoran sapi dengan penambahan serasah daun jati sebanyak 5\% yaitu sebesar $62,25 \mathrm{ml}$.

Rata-rata volume biogas pada beda waktu fermentasi menunjukkan perbedaan yang nyata $(\mathrm{P}<0,05)$. Lamanya waktu fermentasi pada perlakuan kedua substrat feses sapi dan feses kuda menunjukkan adanya peningkatan volume biogas yang dihasilkan dalam digester, semakin lama masa tinggal substrat dalam digester maka akan semakin tinggi volume biogas yang dihasilkan.

Perbedaan level pemberian daun jati pada feses sapi dan feses kuda menunjukkan semakin bertambahnya level pemberian daun jati, dapat menurunkan volume produksi biogas. Penurunan yang sangat nyata terjadi pada biogas menggunakan feses kuda dengan penambahan daun jati sebesar $10 \%$. Berdasarkan data di atas dapat dilihat bahwa terjadi kenaikan pada hari ke 10, 20, 30, dan 40 . Pada biogas dengan substrat feses sapi dan feses kuda terjadi kenaikan yang nyata pada hari ke 30 dan 40 sedangkan pada hari ke 20 kenaikan yang terjadi tidak nyata. Lebih tingginya volume biogas yang dihasilkan dari substrat kuda daripada substrat sapi dapat disebabkan karena perbedaan sistem pencernaan antara sapi dan kuda mengakibatkan kandungan bahan organik dalam feses kuda lebih tinggi daripada bahan organik dalam feses sapi. Pada feses kuda mempunyai kandungan BK lebih tinggi yaitu $96,47 \%$ daripada BK pada feses sapi sebesar $92,12 \%$, selain itu feses kuda mempunyai
$\mathrm{C} / \mathrm{N}$ ratio yang lebih tinggi, yaitu sebesar 25,1 sedangkan feses sapi mempunyai $\mathrm{C} / \mathrm{N}$ ratio sebesar 23,5. Berdasarkan kandungan BK dalam feses sapi dan kuda, diperoleh hasil dalam biogas yang menggunakan feses sapi tanpa penambahan daun jati (kontrol) sebesar 0,00136 ml/100g BK, feses sapi dengan penambahan $5 \%$ daun jati sebesar $0,00123 \mathrm{ml} / 100 \mathrm{~g} \mathrm{BK}$, dan feses sapi dengan penambahan $10 \%$ daun jati sebesar 0,00100 $\mathrm{ml} / 100 \mathrm{~g}$ BK, sedangkan biogas dengan menggunakan feses kuda tanpa penambahan daun jati (kontrol) sebesar 0,00210 ml/100g BK, feses kuda dengan penambahan $5 \%$ daun jati sebesar 0,00195 $\mathrm{ml} / 100 \mathrm{~g}$ BK, dan feses kuda dengan penambahan $10 \%$ daun jati sebesar $0,00159 \mathrm{ml} / 100 \mathrm{~g} \mathrm{BK}$. Menurut data di atas dapat dilihat bahwa biogas dengan menggunakan feses kuda mempunyai volume yang lebih tinggi daripada biogas yang menggunakan feses sapi.

Penurunan volume gas yang sangat nyata terjadi pada biogas menggunakan feses kuda dengan penambahan $10 \%$ daun jati. Tanin berpengaruh terhadap feses kuda dikarenakan feses kuda lebih peka terhadap bahan yang mengandung tanin, sedangkan feses sapi tidak mempunyai pengaruh yang nyata karena feses sapi lebih toleran terhadap tanin yang disebabkan pakan sapi yang banyak terdiri dari daun-daunan. Hasil analisis kimia menunjukkan bahwa daun jati mempunyai kandungan tanin sebesar $16,25 \%$, hal ini dapat menghambat pertumbuhan mikrobia di dalam proses fermentasi metanogenesis.

Menurut Patra et al. (2006) penambahan sisa teh setara $6 \mathrm{mg}$ tanin $/ \mathrm{g}$ substrat menurunkan jumlah protozoa dan konsentrasi ammonia tetapi tidak memberikan efek negatif pada sintesis protein 
mikrobia dan bahkan meningkatkan propionat pada fermentasi rumen. Tanin berpengaruh terhadap pengikatan mikrobia terhadap substrat dan aktivitas enzim (Bento et al., 2005). Gas $\mathrm{H}_{2}, \mathrm{CO}_{2}$ dan asam asetat yang dihasilkan pada tahap pengasaman dengan bantuan bakteri metanogenesis akan membentuk gas $\mathrm{CH}_{4}$ dan $\mathrm{CO}_{2}$ (Fiesinger et al., 2006), dengan demikian penurunan produksi $\mathrm{H}_{2}$ yang disebabkan oleh kandungan tanin dalam serasah daun jati dapat mempengaruhi produksi dan volume gas pada digester.

Tanin yang terkandung dalam daun jati menunjukkan semakin lama waktu fermentasi, akan semakin tidak berpengaruh terhadap volume biogas yang dihasilkan, hal tersebut dapat disebabkan karena semakin lama bakteri yang tinggal di dalam digester dapat beradaptasi dengan kondisi lingkungan di dalam digester. Hal tersebut sesuai dengan pernyataan Kamra (2005) bahwa mikrobia yang berada dalam kondisi anaerob yang di dalamnya terdapat kandungan tanin secara terus menerus akan toleran terhadap tanin.

\section{Kadar metan}

Rata-rata kadar metan pada tiap biogas pada berbagai perlakuan dengan beberapa level pada pengamatan setiap 10 hari sekali, tersaji pada Tabel 3.

Hasil penelitian menunjukkan bahwa rerata kadar metan pada substrat kuda menghasilkan kadar metan yang lebih tinggi yaitu sebesar $36,67 \%$ dibandingkan dengan kadar metan pada biogas dengan menggunakan sustrat feses sapi yang hanya sebesar 33,74\%. Berdasarkan data, terjadi kenaikan yang nyata kadar metan pada hari ke 20, 30, dan 40. Perbedaan level pemberian daun jati pada feses sapi tidak menunjukkan perbedaan yang nyata sedangkan pada feses kuda menunjukkan pada level 10\% pemberian daun jati, dapat menurunkan kadar metan biogas. Kadar metan tertinggi dihasilkan oleh biogas dengan menggunakan substrat feses kuda tanpa penambahan serasah daun jati $(0 \%)$ yaitu sebesar $41,12 \%$, sedangkan kadar metan terendah dihasilkan oleh biogas dengan menggunakan substrat feses kuda dengan penambahan serasah daun jati sebanyak $10 \%$ yaitu sebesar $32,11 \%$. Lebih tingginya kadar metan yang dihasilkan dari substrat kuda daripada substrat sapi dapat disebabkan karena perbedaan sistem pencernaan antara sapi dan kuda, sehingga mengakibatkan kandungan bahan organik dalam feses kuda lebih tinggi daripada bahan organik dalam feses sapi.

Rata-rata kadar metan pada beda waktu fermentasi menunjukkan perbedaan yang nyata $(\mathrm{P}<0,05)$, yaitu substrat feses sapi dengan waktu fermentasi 10, 20, 30, dan 40 hari memiliki hasil berturut-turut yaitu 17,$68 ; 25,51 ; 37,10$ dan 54,65, sedangkan pada substrat feses kuda dengan waktu fermentasi 10, 20, 30, dan 40 hari memiliki hasil berturut-turut yaitu 16,$05 ; 27,63 ; 43,36$ dan 59,63. Lamanya waktu fermentasi pada perlakuan kedua substrat feses sapi dan feses kuda menunjukkan adanya peningkatan kadar metan yang dihasilkan dalam digester.

Pada feses kuda mempunyai kandungan BK lebih tinggi yaitu $96,47 \%$ daripada BK pada feses sapi yang sebesar $92,12 \%$, selain itu feses kuda mempunyai $\mathrm{C} / \mathrm{N}$ ratio yang lebih tinggi yaitu sebesar 25,1 sedangkan feses sapi mempunyai $\mathrm{C} / \mathrm{N}$ ratio sebesar 23,5. Kecernaan selulosa dalam rumen tidak $100 \%$, oleh karena itu dalam feses sapi masih mengandung selulosa yang cukup tinggi. Pada

Tabel 3. Kadar gas metan hasil fermentasi metanogenik yang menggunakan jenis kotoran ternak, konsentrasi dan waktu inkubasi yang berbeda (\%) (levels of methane methanogenic fermentation using manure types, concentrations and different incubation times (\%))

\begin{tabular}{lcccccc}
\hline \hline \multirow{2}{*}{ Substrat (substrate) } & \multirow{2}{*}{$\begin{array}{c}\text { Kons. daun jati (\%) (teak } \\
\text { leaves concentration (\%)) }\end{array}$} & $10\left(10^{\text {th }}\right)$ & $20\left(20^{\text {th }}\right)$ & $30\left(30^{\text {th }}\right)$ & $40\left(40^{\text {th }}\right)$ & $\begin{array}{c}\text { Rerata } \\
(\text { average })\end{array}$ \\
\cline { 3 - 7 } & 0 & 20,69 & 24,78 & 36,50 & 54,77 & $34,21^{\mathrm{c}}$ \\
& 5 & 16,16 & 27,37 & 38,39 & 51,55 & $33,37^{\mathrm{c}}$ \\
& 10 & 16,20 & 24,38 & 36,28 & 57,63 & $33,62^{\mathrm{c}}$ \\
\hline Feses sapi (cow manure) & & 17,68 & 25,51 & 37,10 & 54,65 & 33,74 \\
\hline Rerata (average) & 0 & 18,25 & 36,35 & 46,69 & 63,19 & $41,12^{\mathrm{a}}$ \\
& 5 & 17,70 & 21,37 & 43,09 & 64,99 & $36,78^{\mathrm{b}}$ \\
\multicolumn{1}{c}{ Reses kuda (horse manure) } & 10 & 12,22 & 25,18 & 40,31 & 50,71 & $32,11^{\mathrm{c}}$ \\
\hline *Rerata feses sapi dan kuda & & 16,05 & 27,63 & 43,36 & 59,63 & 36,67 \\
(average of cow manure & & $16,87^{\mathrm{a}}$ & $26,57^{\mathrm{b}}$ & $40,22^{\mathrm{c}}$ & $57,14^{\mathrm{d}}$ & 35,20 \\
and horse manure) & & & & & \\
\hline
\end{tabular}

a,b,c,d Superskrip yang berbeda pada baris/kolom yang sama menunjukkan perbedaan $(\mathrm{P}<0,05)($ different superscripts at the same row/column indicate significant differences $(P<0.05))$. 
rumput Brachiaria ruziziensis mempunyai tingkat kecernaan bahan kering 43-55\%, tingkat kecernaan bahan organik $46-58 \%$ dan tingkat kecernaan protein kasar 45-60\% (Hutasoit, 2009). Hal ini menandakan, pada proses pencernaan yang terjadi di dalam rumen selulosa tidak tercerna seluruhnya.

Rendahnya kadar metan akibat tingginya level daun jati dapat disebabkan karena kandungan tanin yang terdapat pada daun jati. Hasil analisis kimia menunjukkan bahwa daun jati mempunyai kandungan tanin sebesar $16,25 \%$, hal ini dapat menghambat pertumbuhan mikrobia di dalam proses fermentasi metanogenesis. Penurunan kadar metan yang terjadi pada biogas dengan penambahan daun jati dapat disebabkan oleh bakteri metanogenik yang sangat peka terhadap tanin. Penurunan volume gas yang sangat nyata terjadi pada biogas menggunakan feses kuda dengan penambahan 10\% daun jati. Tanin berpengaruh terhadap feses kuda dikarenakan feses kuda lebih peka terhadap bahan yang mengandung tanin, sedangkan feses sapi tidak mempunyai pengaruh yang nyata karena feses sapi lebih toleran terhadap tanin yang disebabkan pakan sapi yang banyak terdiri dari daun-daunan. Pengaruh tanin terhadap $\mathrm{CH}_{4}$, disebabkan penurunan produksi $\mathrm{H}_{2}$ dari sintesis asetat. Hal itu terkait penurunan degradasi serat yang disebabkan penurunan aktivitas mikrobia fibrolitik.

$\mathrm{Gas}_{2}, \mathrm{CO}_{2}$ dan asam asetat yang dihasilkan pada tahap pengasaman dengan bantuan bakteri metanogenesis akan membentuk gas $\mathrm{CH}_{4}$ dan $\mathrm{CO}_{2}$ (Fiesinger et al., 2006), dengan demikian penurunan produksi $\mathrm{H}_{2}$ yang disebabkan oleh kandungan tanin dalam serasah daun jati dapat mempengaruhi produksi dan volume gas pada digester.

Tanin yang terkandung dalam daun jati menunjukkan semakin lama waktu fermentasi akan semakin tidak berpengaruh terhadap volume biogas yang dihasilkan, hal tersebut dapat disebabkan karena semakin lama bakteri di dalam digester mengakibatkan bakteri sudah dapat beradaptasi dengan lingkungan digester. Hal tersebut sesuai dengan pernyataan Kamra (2005) bahwa mikrobia yang berada dalam kondisi anaerob yang di dalamnya terdapat kandungan tanin secara terus menerus akan toleran terhadap tanin.

Rata-rata produksi metan pada tiap biogas pada berbagai perlakuan dengan beberapa level pada pengamatan setiap 10 hari sekali, tersaji pada Tabel 4.

Data yang dihasilkan menunjukkan bahwa produksi metan memiliki rerata tertinggi oleh biogas dengan biogas menggunakan feses kuda tanpa penambahan serasah daun jati $(0 \%)$ yaitu sebesar 41,12 $\mathrm{ml}$, sedangkan rerata terendah dihasilkan oleh biogas menggunakan feses sapi dengan penambahan serasah daun jati sebanyak $5 \%$ yaitu sebesar 31,21 ml. Hal ini dikarenakan kotoran kuda mempuyai kandungan $\mathrm{C} / \mathrm{N}$ ratio $25 \%$ lebih tinggi daripada $\mathrm{C} / \mathrm{N}$ ratio kotoran sapi yang mempunyai nilai $\mathrm{C} / \mathrm{N}$ ratio $18 \%$, selain itu kotoran kuda juga mempunyai kadar nitrogen $(\mathrm{N})$ sebesar $2,8 \%$, lebih tinggi daripada kadar $\mathrm{N}$ dalam kotoran sapi (Suriawiria dan Sastramihardja, 1980).

Rata-rata produksi metan pada beda waktu fermentasi menunjukkan perbedaan yang nyata $(\mathrm{P}<0,05)$. Data di atas menunjukkan bahwa penggunaan substrat feses kuda menghasilkan produksi gas metan yang lebih tinggi. Peningkatan level pemberian serasah daun jati menunjukkan penurunan bertambahnya masa tinggal fermentasi pada digester menghasilkan peningkatan produksi metan dalam digester.

Tabel 4. Produksi gas metan $\left(\mathrm{CH}_{4}\right)$ hasil fermentasi metanogenik yang menggunakan jenis kotoran ternak, konsentrasi dan waktu inkubasi yang berbeda ( $\mathrm{ml} /$ fermentor) (the production of methane gas $\left(\mathrm{CH}_{4}\right)$ methanogenic fermentation using manure types, concentration and different incubation times (ml/fementor))

\begin{tabular}{lcccccc}
\hline \hline \multirow{2}{*}{$\begin{array}{c}\text { Substrat (substrate) } \\
\text { Kons. daun jati (\%) (teak }\end{array}$} & \multicolumn{5}{c}{ Hari ke (days) } \\
\cline { 3 - 7 } & leaves concentration (\%) & $10\left(10^{\text {th }}\right)$ & $20\left(20^{\text {th }}\right)$ & $30\left(30^{\text {th }}\right)$ & $40\left(40^{\text {th }}\right)$ & $\begin{array}{c}\text { Rerata } \\
(\text { average })\end{array}$ \\
\hline Feses sapi (cow manure) & 0 & 9,06 & 16,72 & 28,38 & 84,25 & $34,61^{\text {cd }}$ \\
& 5 & 3,96 & 13,73 & 34,17 & 72,99 & $31,21^{\text {cd }}$ \\
& 10 & 3,02 & 7,45 & 25,54 & 74,48 & $27,71^{\text {d }}$ \\
\hline Rerata (average) & 0 & 5,34 & 12,60 & 29,36 & 77,24 & 31,13 \\
\hline Feses kuda (horse manure) & 5 & 12,69 & 31,86 & 67,86 & 153,53 & $41,12^{\mathrm{a}}$ \\
& 10 & 14,76 & 21,77 & 58,20 & 120,72 & $53,86^{\mathrm{b}}$ \\
& & 7,37 & 22,84 & 46,12 & 74,61 & $37,73^{\mathrm{c}}$ \\
\hline Rerata (average) & & 11,60 & 25,49 & 57,39 & 116,28 & 52,69 \\
\hline *Rerata feses sapi dan kuda & & $8,47^{\mathrm{a}}$ & $19,04^{\mathrm{b}}$ & $43,37^{\mathrm{c}}$ & $96,76^{\mathrm{d}}$ & 41,91 \\
(average of cow feaces and & & & & & \\
horse feaces) & & & & & \\
\hline
\end{tabular}

${ }^{\text {a,b,c,d }}$ Superskrip yang berbeda pada baris/kolom yang sama menunjukkan perbedaan $(\mathrm{P}<0,05)($ different superscripts at the same row/column indicate significant differences $(P<0.05))$. 
Pada feses kuda mempunyai kandungan BK lebih tinggi yaitu $96,47 \%$ daripada BK pada feses sapi yang sebesar $92,12 \%$, selain itu feses kuda mempunyai $\mathrm{C} / \mathrm{N}$ ratio yang lebih tinggi, yaitu sebesar 25,1 sedangkan feses sapi mempunyai $\mathrm{C} / \mathrm{N}$ ratio sebesar 23,5. Berdasarkan kandungan $\mathrm{BK}$ dalam feses sapi dan kuda diperoleh nilai volume gas $(\mathrm{ml} / 100 \mathrm{~g} \quad \mathrm{BK})$, sehingga diperoleh nilai produksi gas pada biogas dengan menggunakan feses sapi tanpa penambahan daun jati (kontrol) sebesar $0,0465 \mathrm{ml} / 100 \mathrm{~g} \mathrm{BK}$, feses sapi dengan penambahan $5 \%$ daun jati sebesar $0,0410 \mathrm{ml} / 100 \mathrm{~g}$ BK dan feses sapi dengan penambahan $10 \%$ daun jati sebesar $0,0336 \mathrm{ml} / 100 \mathrm{~g}$ BK, sedangkan pada biogas dengan menggunakan feses kuda tanpa penambahan daun jati (kontrol) sebesar 0,0863 $\mathrm{ml} / 100 \mathrm{~g}$ BK, feses kuda dengan penambahan $5 \%$ daun jati sebesar $0,0717 \mathrm{ml} / 100 \mathrm{~g}$ BK dan feses kuda dengan penambahan $10 \%$ daun jati sebesar $0,0510 \mathrm{ml} / 100 \mathrm{~g}$ BK. Penurunan yang terjadi pada ladar metan mempengaruhi turunnya produksi gas metan, hal ini disebabkan karena bakteri metanogenik yang sangat peka terhadap tanin.

Data di atas sesuai dengan penelitian Shuler dan Kargi (2002) yang menyatakan pembentukan metan dipengaruhi oleh pertumbuhan bakteri metanogenik yang mengubah asam volatile menjadi metan dan $\mathrm{CO}_{2}$ dan produk akhir lain sehingga laju pembentukan metan seiring dengan laju pertumbuhan bakteri metanogenik. Penurunan yang terjadi pada kadar metan mempengaruhi turunnya produksi gas metan, hal ini disebabkan karena bakteri metanogenik yang sangat peka terhadap tanin, hal ini sesuai dengan penelitian Fiesinger et al. (2006) bahwa penurunan produksi $\mathrm{H}_{2}$ yang disebabkan oleh kandungan tanin dalam serasah daun jati dapat mempengaruhi produksi dan volume gas pada digester.

\section{Kesimpulan dan Saran}

\section{Kesimpulan}

Feses sapi dan feses kuda dapat digunakan sebagai sumber energi pembuatan biogas, namun penambahan daun jati sebagai sumber carbon yang berfungsi untuk meningkatkan rasio $\mathrm{C} / \mathrm{N}$ dengan harapan dapat meningkatkan produksi metan tidak dapat meningkatkan produksi biogas bahkan dapat menimbulkan penurunan produksi gas pada kuda.

\section{Saran}

Perlu dilakukan penelitian lebih lanjut mengenai level penambahan serasah daun jati (Tectona grandis) sebagai sumber carbon sehingga dapat diketahui titik optimal yang dapat ditambahkan sebagai sumber carbon.

\section{Daftar Pustaka}

Asro. 2008. Pengukuran TOC (1-Prinsip Kerja). Wordpress, category laboratory instrument. http://go2.wordpress.com.

Astuti, M. 1981. Rancangan Percobaan dan Analisis Statistik. Fakultas Peternakan. Universitas Gadjah Mada. Yogyakarta.

Bento, M.H.L., T. Acamovic, and H.P.S. Makkar. 2005. The influence of tannin, pectin and polyethylene glycol on attachment of $15 \mathrm{~N}-$ labelled rumen microorganism to cellulose. Anim. Feed Sci. and Technol. 122: 41-57

Fiesinger, T., B.D. Roloson, N. R. Scoot, K. Bothi, K. Sakkonen, and S. Zicari. 2006. Biogas Processing. New York State Electric and Gas Corporation Cornell University Ithaca, New York.

Hartono, R. 2009. Produksi Biogas dari Jerami Padi dengan Penambahan Kotoran Kerbau. Seminar Nasional Teknik Kimia Indonesia SNTKI 2009 ISBN 978-979-98300-1-2. Bandung, 19-20 Oktober 2009.

Hutasoit, R. 2009. Budidaya dan pemanfaatan Bachiaria ruziziensis (rumput ruzi) sebagai hijauan pakan kambing. Pusat Penelitian dan Pengembangan Peternakan Badan Penelitian dan Pengembangan Pertanian Departemen Pertanian 2009 ISBN: 978-602-8475-03-7.

Kamra, D.N. 2005. Rumen microbial ecosystem. Current Science. 89(1): 124-135.

Mustafa. 2005. Peranan makrofauna tanah dalam proses dekomposisi serasah acacia mangium willd. Biodiversitas 6(1): 63-65.

Patra, A.K., D.N. Kamra, and N. Agarwal. 2006. Effect of plant extracts on in vitro metanogenesis, enzyme activities and fermentation of feed in rumen liquor of buffalo. Anim. Feed Sci. and Technol. 128: 276-291.

Perum Perhutani. 2000. Marketing and Trade Policy of Perum Perhutani. Dalam: Hardiyanto, Eko B. (peny.). Proceeding of the Third Regional Seminar on Teak. Yogyakarta, Indonesia. July 31- August 4, 2000. Yogyakarta: Fakultas Kehutanan UGM, Perum Perhutani, dan TEAKNET-Wilayah Asia Pasifik.

SAS Institute Inc. 1988. SAS/ETS 9.22 User's Guide. Cary, NC: SAS Institute Inc

Shuler, M.L. and F. Kargi. 2002. Bioproses Engineering. Second ed. Prentice-Hall, Inc., USA.

Siallagan, R. 2010. Pengaruh waktu tinggal dan komposisi bahan baku pada proses fermentasi limbah cair industri tahu terhadap produksi biogas. Fakultas Teknik Program Magister 
Teknik Kimia Universitas Sumatera Utara, Medan.

Sihotang, B. 2010. Kandungan Senyawa Kimia Pada Pupuk Kandang Berdasarkan Jenis Binatangnya. Avaliable at r.yuwie.com/blog/ entry. Accession date: 29 November 2010.

Suriawiria dan Sastramihardja. 1980. Faktor Lingkungan Biotis dan Abiotis di Dalam Proses Pembentukan Biogas serta Kemungkinan Penggunaan Starter Efektif di
Dalamnya. Lokakarya Pengembangan Energi Non-Konvensional. Direktorat Jenderal Ketenagaan Departemen Pertambangan dan Energi, Jakarta.

Widodo, T. 2006. Rekayasa dan pengujian reactor biogas skala kelompok tani ternak. Jurnal Engeneering Pertanian Balai Besar Pengembangan Mekanisme Pertanian. 4 (1): 1- 4. 